\title{
Micro-enterprise predicament in township economic development: Evidence from Ivory Park and Tembisa
}

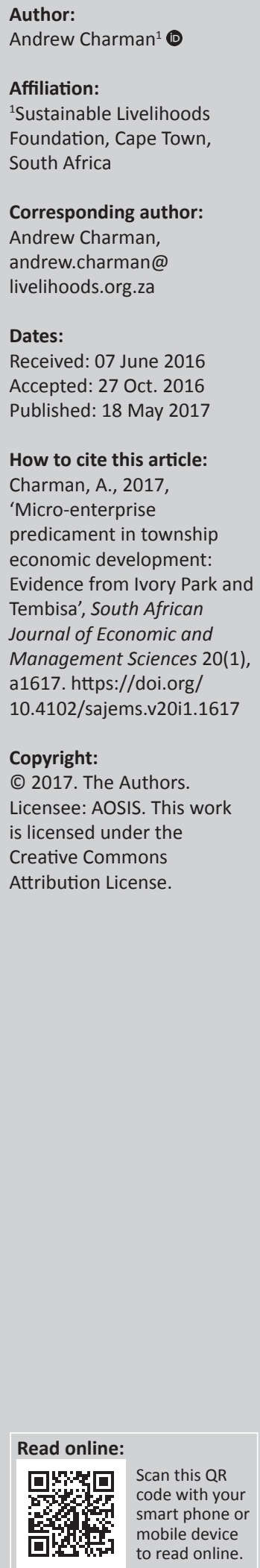

Background: In South Africa, the idea that the township economy needs to be 'revitalised' has begun to gain significant political traction. The Gauteng provincial government has responded to this challenge by setting out a strategy that promises to channel resources and create opportunities for micro-enterprises. The paper responds to development interventions such as this through interrogating the nature of the challenges facing micro-enterprises that need to be overcome in South African townships.

Aim: In response to the developmental need to stimulate micro-enterprise growth in South African townships, the paper poses the question: what approaches are most likely to have a positive impact on township businesses, given current micro-enterprise dynamics?

Setting: Primary research was undertaken in two neighbouring townships in Gauteng province, in Ivory Park and Tembisa.

Methods: The data comprises a geospatial census of enterprise activities, a survey of select firms and qualitative interviews with business owners. The research utilised a small-area census approach to obtain data on business activities within an area of approximately $2 \mathrm{~km}^{2}$ in each site. The census enumerated 2509 micro-enterprises in Ivory Park and 1722 microenterprises in Tembisa. Firm interviews were conducted with business owners in four sectors: grocery retail, liquor retail, hair care and early childhood development centres.

Results: The business census identifies a strong similarity in the structure of the townships' informal micro-entrepreneurship despite the considerable differences in the socio-economic status of the respective case sites. The enterprise survey highlights the resource constraints of township businesses and thinness of local markets. Interviews with entrepreneurs reveal four main pathways through which individuals enter into self-employment with the most dynamic enterprises established by inward investing entrepreneurs. Spatial considerations exert an influence on the position of enterprise sectors, whilst access to land and business infrastructure are notable constraints.

Conclusion: Reflecting on the evidence, the paper concludes with making a call for a more low-geared development approach, focusing on lessening the legal, institutional and regulatory obstacles to enterprise growth as a first step. Municipalities have an important role in liberalising the spaces and places where township informal enterprises can and should be permitted to trade as well as creating a more favourable business environment. The challenges of crime and finance demand more purposeful action from the national government.

\section{Introduction}

In South Africa, the idea that the township economy needs to be 'revitalised' has begun to gain significant political traction. For a while it had seemed as though the informal economy ${ }^{1}$ and micro-enterprises ${ }^{2}$ had fallen off the developmental radar, with the National Development Plan (NDP) focusing on job creation in the formal economy. Fourie (2015:14) argues that the NDP provides inadequate attention to the 'unique obstacles faced by micro-enterprises in the margins of the economy'. That current policy blind spot is not only specific to South Africa but is also noted in low-income sub-Saharan African development strategies in general, where informal micro-enterprises have much potential for job creation (Fox \& Sohnese 2012; Ligthelm 2006; Mead \& Liedholm 1988). Whereas the national government may have an ambivalent approach to the informal economy and micro-enterprises, the Gauteng provincial government has positioned 1.The informal economy is understood to consist of partially or completely unregistered and unregulated businesses, and includes unregistered employees.

2.A 'microenterprise' refers to a small business that is usually not registered for business tax and which typically employs fewer than five employees, engaged to work on an informal basis. 
itself squarely in support of reviving the economic margins. Its objectives in this respect are set out in a strategy document 'Revitalisation of the Township Economy' (2015). The strategy details a plan of action through which the government seeks to channel resources and create opportunities to foster an inclusive economy based on the promotion of manufacturing, support for cooperatives, and the growth of opportunities in retail and financial services. But what precisely are the challenges for micro-enterprises that need to be overcome in South African townships?

This paper seeks to encourage reflection on the kinds of enterprise development interventions that might be possible, or indeed feasible, in urban townships. To explore such possibilities and practicalities, the aim is to examine actual informal micro-enterprise activities, their scope and scale, and the reported challenges of doing business in two specific township contexts in Gauteng, namely in the settlements of Ivory Park and Tembisa. The paper seeks to address questions about what business activities occur, where people conduct business, how entrepreneurs enter into the township informal economy, what challenges they face and how they respond to these issues. The emphasis in this paper is on the geographical context of the township, rather than on the size of the businesses operating therein - although most of the businesses in this study are 'micro' in size vis-à-vis assets and employment criteria - or the position of the enterprise relative to institutional processes of regulation. Our perspective includes micro-enterprises that are partially or fully legal and those that are illegal, and engaged in both licit and illicit activities.

\section{Literature review}

There is a wide literature on informal micro-enterprises, and considerable research has focused on the South African context. Macro studies, drawing on nationally and regionally representative data sets, such as the Statistics South Africa Quarterly Labour Force Survey (QLFS), or independent surveys such as the one undertaken by the Finmark Trust (Finscope 2010), provide a generalised indication of the sectors in which the self-employed participate and some indication of informal micro-enterprise dynamics. The literature raises two main concerns. First is a concern that the level of participation in micro-enterprise activities (including informal employment) is low, in relative and absolute terms (Wills 2009; Yu 2012). The developmental implication is that unemployed persons are reluctant or unable to pursue self-employed businesses. In seeking to understand motivational factors, research has examined sociocultural considerations such as perceived barriers towards self-employment amongst the unemployed (Cichello et al. 2011). The Cichello study identified crime, the high costs of capital, transport costs, fear of failure and jealousy as obstacles that hinder a more widespread embracing of selfemployment. The second concern is that the structure of the township economy is dominated by small-scale trade in food and/or consumables, serving 'thin' localised markets with 'weak effective demand' (Mahajan 2014), whilst the retail sector in general has come under increasing competition from supermarkets and large retailers, thus reducing opportunities (Charman, Petersen \& Piper 2012; Ligthelm 2008; Piper \& Yu 2016). The FinScope survey (2010), which prides itself on being the 'first study being able to provide a credible sense of the size and dynamics of the South African small business sector' (2010:7), found that $78.7 \%$ of small businesses are retail oriented (21.3\% service-oriented), though in Gauteng province service businesses increased proportionally to $34 \%$.

Sector-specific studies, using qualitative and/or quantitative methods, have sought to examine entrepreneurial and firm dynamics (including resource allocation) and motivational considerations amongst township entrepreneurs. These include writings on grocery retail outlets (spaza shops) (Ligthelm 2005; Charman \& Piper 2013), liquor retailers (Charman, Herrick \& Petersen 2014; Rogerson \& Beavon 1982), traditional healers (Petersen et al. 2014) and township tourism enterprises (Nemasetoni \& Rogerson 2005) to list four examples. Research on street traders, in contrast, has predominately investigated urban inner-city informal markets and central business district localities (see BenitGbaffou 2015; Skinner 2008). Sector studies permit a more nuanced understanding of entrepreneurship. For example, writers have highlighted the considerable differences between large (more sustainable and entrepreneurial) and small (though nevertheless resilient) enterprises. The concern with differentiated enterprise size has helped bring about the idea of 'survival' or 'survivalist' businesses: micro-enterprises that are not deemed to derive from entrepreneurial motivation (for one of the original uses of the survival concept, see Mead \& Liedholm 1988). The projection of the analytic lens on 'survival' has also drawn our attention to the structural weaknesses of informal township enterprises as a result of under-capitalisation and resource constraints (Rolfe et al. 2010).

Counter to the concern with slow or little growth amongst survivalists, Neves and Du Toit (2012) have indicated that township enterprise activities are embedded in a social context where relationships of mutual support and reciprocity can be as important as profit motives, whilst economic participation itself serves a social function and reinforces peoples' sense of belonging, place in community and selfidentity. This argument aligns with institutional theory's tenet that enterprise decisions are influenced by both formal institutions (laws, regulations etc.) and informal institutions (consensual agreements, moral practices etc.). In consequence, Webb et al. (2013:601-602) argue that the 'incongruence' between formal and informal institutions' conception of social acceptability enables 'opportunity recognition' for informal entrepreneurs, a process which in the township environment explains the widespread illicit sale of both licit (such as beer and pharmaceuticals) and illicit products (such as drugs, traditional medicines and grey market goods).

Area studies have sought to understand the influence of the specific socio-political and urban context on enterprise activities (or absence thereof). These include 
the World Bank-funded study of the Diepsloot township economy (Mahajan 2014; Mengistae 2014) and the business census studies in five Cape Town townships (Charman \& Petersen 2014). The area approach allows researchers to interrogate notions about the kinds of enterprises that operate within a geographical environment and their business dynamics. Mengistae (2014:192), for instance, found that despite the constraints on business growth, $40 \%$ of the surveyed enterprises reported to operate on a larger scale than when starting out and concluded that even survival businesses have growth potential. The finding that time helps' is consistent with research elsewhere on the African continent (Gulyani \& Talukdar 2010; McPhersen 1996; Mead \& Liedholm 1998). Yet the comparative literature offers caveats. Gulyani and Talukdar (2010:1711, 1722) emphasise that 'living conditions matter', bearing an influence on the formation of the enterprise as well as its performance. Of relevance to the South African situation is their finding from Nairobi slums that those informal enterprises that sell their goods (or a portion thereof) outside the settlement are less likely to be poor. It is also important to note McPhersen's (1996:274) finding that human capital has a significant bearing on enterprise growth, such that those entrepreneurs with experience, education and training are better able to grow their businesses than persons with less such capital.

South African researchers have devoted little attention to understanding the impact of the institutional context on township business development. Research in the Global North recognises the polycentricism of policy approaches (especially differences between national and local levels) with respect to the institutional process of business regulation and divergences in enforcement in stimulating informal entrepreneurship (Webb et al. 2013). In this respect, the township informal economy has enabled certain kinds of entrepreneurs (both local residents and outsiders) to take advantage of the 'ambiguities' around jurisdiction to operate businesses, which, outside the township, would confront more onerous state control. Some of the examples in the literature are 'large' informal retailers (Liedeman 2012), traditional healers and unregistered health services (Petersen et al. 2014), and gambling rings (Scott \& Barr 2013). Additionally, the institutional barriers that confront township entrepreneurs are inadequately understood, apart from those sectors where regulation a priori determines formalisation. Understanding these obstacles is important if facilitation towards formalisation is to be embraced as a policy strategy, an approach that is currently not part of the discussion on township economy development. A developmental approach to business regulation is considered to be the most viable option given the recognised limitations inherent in the 'do nothing' and 'eradication' policy strategies (for a review, see Williams \& Nadin 2014, 2012).

The paper now turns to the two case sites to examine entrepreneurial constraints facing township microenterprises. The paper is structured into four further sections. Firstly, the paper introduces the case sites, providing an overview of their contrasting histories and demographic profiles. Secondly, we detail the methods utilised to gather data through an enterprise census and qualitative firm survey. Thirdly, the article examines the results. We first highlight the surprising similarities between the two case sites in the range of enterprises and their distribution. We then distinguish the different pathways that entrepreneurs have taken to establish their business. Then we describe the main obstacles that micro-enterprises confront. Fourthly and finally, the paper takes a sober reflection on the question posed at the outset: what developments are achievable given the business dynamics identified? The paper concludes with making a call for a more low-geared approach to township economic development, focusing on lessening the legal, institutional and regulatory obstacles to enterprise growth as a first step.

\section{Case sites: Ivory Park and Tembisa}

The case sites are portions of two adjoining townships: Ivory Park, which falls into the City of Johannesburg, and Tembisa, which falls into the City of Ekurhuleni. Our focus is on the sub-place areas of Section 2 and Section 5 in Ivory Park and the neighbourhoods of Entshonalanga, Umnonjaneni, Moedi, Khatamping, Endayini, Umfuyaneni and Umthambeka in Tembisa. In both cases, the research sites measure approximately $1.6 \mathrm{~km}^{2}$. The two townships are situated in Gauteng province. In topographical terms, the sites are divided by a small stream, though share a common spatial geography in relation to the broader metropolitan area. In their settlement histories, layout and demographic profiles, Ivory Park and Tembisa differ significantly. In the spatial segments under examination, there are no formally established markets. Instead, businesses have silently 'encroached' (Bayat 1977) and now operate from 'public space', homes, utility servitudes and streets.

Ivory Park is a post-apartheid township. It was established in 1996 on a site at which an informal settlement had emerged (Mahon 2010). The new settlement accommodated residents from overcrowded townships including Alexandra. As a result of informal settlement, the urban planning process had to align with land claims and settlement patterns. The street layout is haphazard apart from the 'high streets' that bisect the settlement and provide transport corridors linking Ivory Park to Tembisa and the major North-South freeway arteries. Under the government Reconstruction and Development Programme, the first generation of settlers obtained brick and mortar housings. The settlement has also benefited from a modicum of social infrastructure, including schools, a taxi rank, a police station and a clinic. Today, all land within the township (apart from a few parcels reserved for commercial activities) is occupied with settlement. Tembisa was established in 1957 (SAHA n.d.). The settlement, in spatial terms, epitomises apartheid modernist planning, the streets laid out in a grid pattern, social infrastructure clustered in the centre of each segment, positioned on the hill ridges, and a green fringe preserved on the perimeter. The population is ethnically heterogeneous with the largest group, isiZulu, 
TABLE 1: Ivory Park and Tembisa, comparative socio-economic indicators.

\begin{tabular}{lcccccccccc}
\hline Site & $\begin{array}{c}\text { Total } \\
\text { population }\end{array}$ & $\begin{array}{c}\text { Total } \\
\text { households }\end{array}$ & $\begin{array}{c}\text { Female } \\
\text { population (\%) }\end{array}$ & $\begin{array}{c}\text { Population in } \\
\text { informal } \\
\text { settlements (\%) }\end{array}$ & $\begin{array}{c}\text { No-income (\%) } \\
\text { R1-R9600 (\%) }\end{array}$ & $\begin{array}{c}\text { R9601-R38 200 } \\
\text { (\%) }\end{array}$ & $\begin{array}{c}\text { R38 201- } \\
\mathbf{1 5 3} 800(\%)\end{array}$ & $\begin{array}{c}\text { R153 801- } \\
\text { R614 400 (\%) }\end{array}$ & $\begin{array}{c}\text { Above R614 001 } \\
\text { (\%) }\end{array}$ \\
\hline Ivory Park & 45453 & 19146 & 46 & 13 & 22.6 & 10.6 & 40.61 & 24 \\
Tembisa & 41673 & 10467 & 49 & 4 & 19.5 & 7.7 & 33.94 & 34 \\
\hline
\end{tabular}

Source: Statistics South Africa, Population census 2011, viewed n.d., from https://www.census2011.co.za

accounting for one-third of the total. Over time, the settlement has changed in size and composition, with neighbourhoods becoming less ethnically segregated and notable investments in home improvements. In the neighbourhoods under consideration, one neighbourhood has informal dwellings within this neighbourhood less than $4 \%$ of the households reside informally.

Despite their dissimilarities (historical, spatial, demographic and structural), the two settlements share similar characteristics in socio-economic profiles. Unemployment is high $(31.4 \%$ in Ivory Park and $34.5 \%$ in Tembisa, narrow definition) and spatially distributed across both sites. In terms of income distribution (using the 2011 StatisticsSA census data, categorised in quintiles), about one-fifth of households report 'no-income', 34\% - 40\% earn between R9600 and R38 000 per annum, and a further 24\% - 34\% earn between R38 001 and R153 800 per annum (see Table 1). The latter cohort approximate to full-time salaried workers. In both settlements the 'middle class' comprises less than 5\% of the population. The proportional income distribution across quintiles suggests that households in Tembisa have marginally higher income than those in Ivory Park. It is possible that the official census data under-report informal income streams from business activities, accommodation rental, welfare transfers and private transfers.

Ivory Park accommodates a substantial community of migrants and immigrants. The census data indicate that $29 \%$ of the population gave their home language as Xitsonga, isiNdebele and other, thus potentially including Mozambicans and Zimbabweans. Some of the new settlers reside in shack settlements, which accommodate $13 \%$ of the population in Ivory Park, although most migrants and/or immigrants are accommodated in single dwelling 'backyard' structures built by the house owners who have thus acquired a highly profitable and reliable income stream.

\section{Research methods and analysis}

Field research was undertaken over the period May 2012 August 2012. The research formed part of a project to study the township informal economy in various localities. ${ }^{3}$ The research methods comprised two main components: a census of business activities and a business survey. The research utilised a mixture of qualitative and quantitative methods in a small-area census approach, described in Charman et al. (2015). The data collection process entailed traversing every street, pathway and passage within a specific area, recording the spatial position and activity of each identified business, undertaking a survey of specific businesses, and gathering data from conversations, collecting artefacts (such as flyers, posters) and taking photographs of business activities and contexts. The survey component was not applied universally but targeted to particular sectors and within sectors to businesses with specific characteristics. The focus was on sectors considered to be most significant (numerically and in terms of their potential for business growth). These were grocery shops (known as spaza shops), taverns (and shebeens, an unlicensed liquor retail outlet), hair salons and businesses providing child care (known as educares). In addition, the research protocol restricted the interviews to enterprises that met the following criteria: businesses had to have dedicated infrastructure (however modest, including a room in a house), have a commercial identity (a name or signage) and trade on a regular basis. In most cases, the targeted businesses were micro in size, evident in the modesty of assets and sole proprietorship, with employment uncommon and restricted to part-time workers and occasional family assistance. All enterprises traded solely in cash.

The data from the census were extracted from the geographic information system (GIS) devices and compiled into a data set. Based on preliminary enterprise categorisation, field notes and photographs, each entry was classified into one of 34 categories of business activities (reflecting the goods and services provided; not industrial classifications which are inappropriate in their aggregation; see Wills 2009) and ordered according to the primary, secondary or subsidiary business activity. The classification of businesses on their spatial location, such as the street, was avoided where their activity, such as selling fruit and vegetables, could be more accurately reflected within a sector categorisation. The survey data were recorded on paper questionnaires and were subsequently transferred to a database and categorised to enable comparative analysis (following suggestions on data organisation in Creswell 2014). The qualitative responses were examined to identify core themes and substantiate the analysis with human voices. Where first names are given, these are the actual names of the business owners, though their identities remain otherwise anonymous. The reference refers to a unique identification number in the data set. The research also draws on personal observations and/or field notes from having criss-crossed both settlements and engaged in dozens of conversations.

\section{Results \\ Similarities in scope and scale}

The results of the enterprise census are summarised in Table 2. The census identified 2509 enterprise activities in Ivory Park and 1722 in Tembisa. This equates to 55.1 
enterprises per 1000 people for Ivory Park and 38.4 for Tembisa and 13.1 per 100 households in Ivory Park against 9 per 100 households in Tembisa. The level of entrepreneurship is substantially higher in Ivory Park and comparatively higher than other township sites we have studied in the Western Cape where we identified an average of 30 enterprises per 1000 people or 9.7 per 100 households (Charman \& Petersen 2014). The heightened level of business activity in Ivory Park is probably attributable to a combination of

TABLE 2: Summary of enterprise census results.

\begin{tabular}{llc}
\hline Site & Variable & Data \\
\hline Ivory Park & Total enterprises & 2509 \\
& Enterprises per 1000 population & 55.1 \\
& Enterprises per 100 HHs & 13.1 \\
& Percentage of enterprises on the high street & 31.9 \\
Tembisa & Total enterprises & 1722 \\
& Enterprises per 1000 population & 38.4 \\
& Enterprises per 100 HHs & 9.0 \\
& Percentage of enterprises on the high street & 34.0 \\
\hline
\end{tabular}

$\mathrm{HH}$, Household. factors, though two influences are notable. Firstly, immigrant entrepreneurs have responded to their economic situation through creating new opportunities (or 'make work jobs', Mukhopadhyay 2011); secondly, entrepreneurship benefits as a result of the broader scope for informalisation within Ivory Park, such as the spatial opportunities to conduct business in the street environment, utility servitudes and private households and so forth.

Though there are more micro-enterprises in Ivory Park than in Tembisa, the structure of the neighbourhood economies is not substantially different. This is a surprising result given the differences between the two settlements. Figures 1 and 2 show the distribution of micro-enterprise activities per 1000 people in Ivory Park and Tembisa, respectively, across the 34 business categories. In Ivory Park, the top five ranking (in terms of percentage) are house shops $(17.1 \%)$, street trade $(12.5 \%)$, taverns and/or shebeens $(9 \%)$, grocery retail $(7.2 \%)$ and green grocer and takeaways tied $(5.7 \%)$, whereas Tembisa's top five are house shops $(25 \%)$, grocery retail $(8.9 \%)$, taverns and/or shebeens $(8.5 \%)$, street trade $(6.9 \%)$

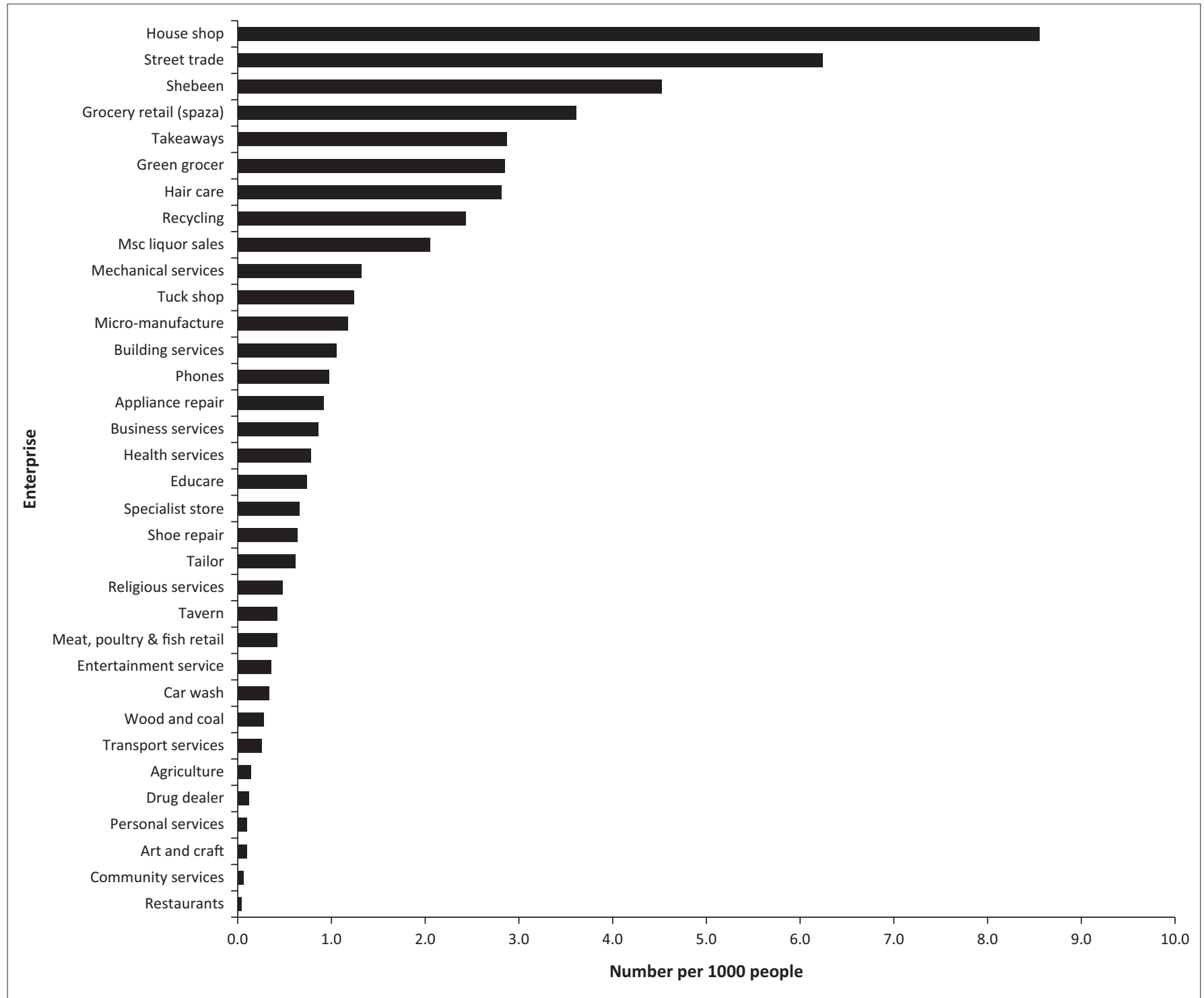

FIGURE 1: Ivory Park, enterprise activities per 1000 people. 


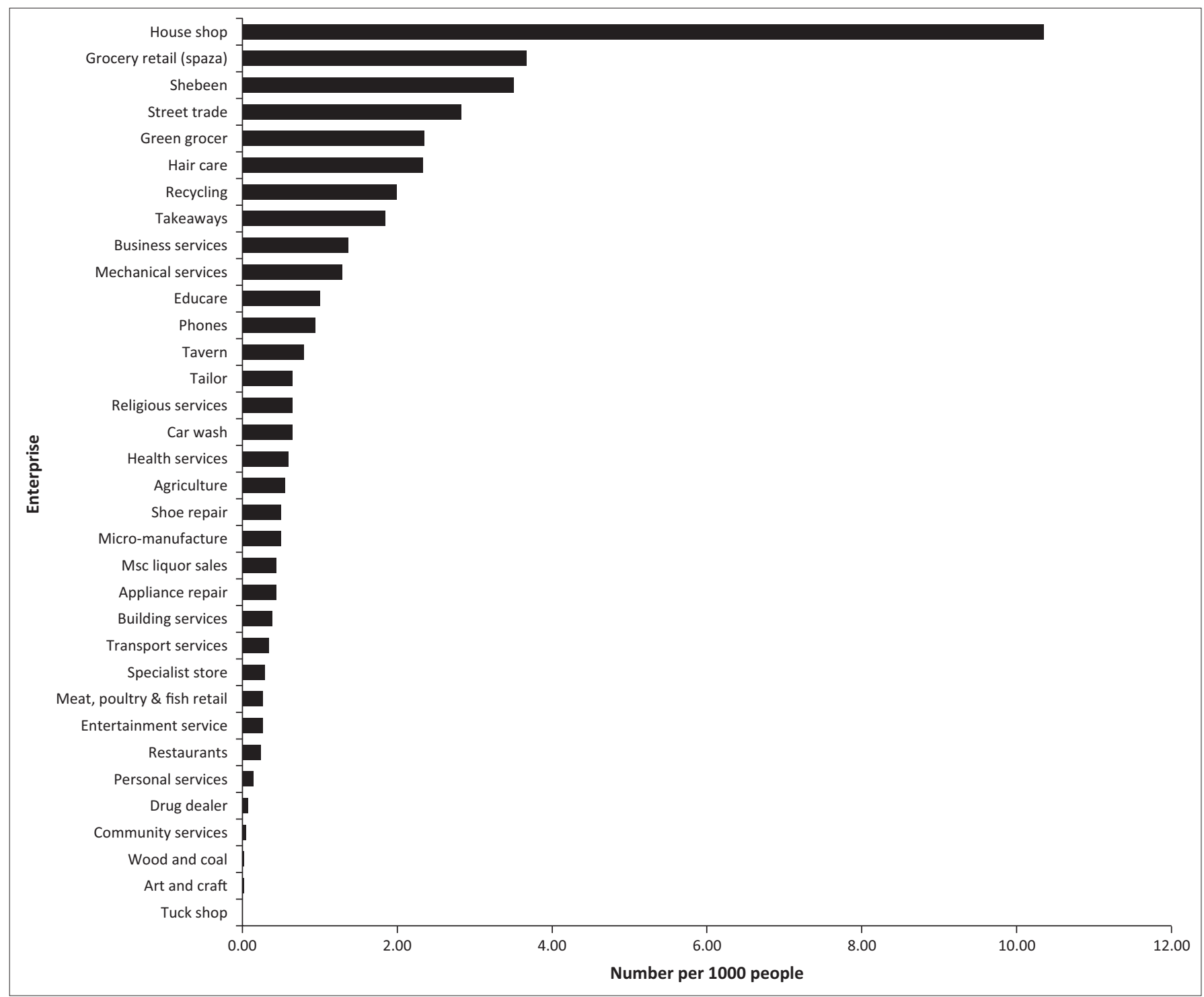

FIGURE 2: Tembisa, enterprise activities per 1000 people.

and green grocers (5.7\%). In both townships, hair care services occupy the next place with $5.6 \%$ of all identified activities. The sale of food (groceries, fresh produce, meat and poultry), beverages (cold drinks and alcohol) and prepared foods (street food, takeaways and restaurants) equates to over $50 \%$ of all business activities in both sites (53.1\% Ivory Park; 56.7\% Tembisa), a finding that is similar to the results found in Diepsloot (Mengistae 2014). Servicerelated enterprises, including hair care, health services, building services (construction), business services, repair services, mechanical services, religious services, educational services and transport services, comprise 18.7\% in Ivory Park and $23 \%$ in Tembisa. Micro-manufacturing, which includes activities related to the production of arts and crafts, furniture, cobbling and clothes making, comprises $5.1 \%$ of activities in Ivory Park and $4.1 \%$ in Tembisa.

The small-scale of micro-manufacturing, relative to all activities, might be anticipated, though the significance of the sector should not be overstated. Most of the businesses were artisanal producers, making items such as burglar bars and gates, cupboards, prefabricated 'zozo' huts, beds and mattresses made with recycled springs, dresses and shoes (particularly in 'ethnic' styles). There were examples of collaborative production (in bed making), though limited evidence of employment and downstream value chain links. In most cases, manufactured wares were sold at the point of production which was usually on the street or an open piece of land. Amongst the artisanal crafts persons, some have advanced skills though many exhibit rudimentary skills. The use of hand tools predominates. These craft persons tend to work alone (though immigrant furniture makers work in small groups), replenishing materials once products are sold and trade at the point of production. Core business strategies of these entrepreneurs are, one, to produce goods of 'cultural' value, two, to provide customised items for home renovations (gates and burglar bars), three, to sell products that are cheaper (in many cases because the product is knowingly inferior) and four, to target persons unable to purchase from formal stores (because they cannot access credit and/or acquire furniture on hire purchase). 


\section{Enterprise characteristics}

\section{Spatial influences}

Business activities are conducted in different spatial localities. The home, or residential context, is especially important for retailers operating within a house or shack selling groceries, snacks, cold drinks, liquor and fast food such as 'kota' (bread and filling) outlets. Education services, such as crèches and educares, are usually home-based, as are businesses that collect scrap materials and need the storage space of a yard. The street hosts a different range of businesses. These include green grocers, street fast food outlets (such as braai stands), hair care businesses and ambulatory hawkers selling anything from clothes to homeware (brooms, dish towels, dusters, etc.). Across the range of street environments, the 'high street' (major roads and transit routes) is particularly significant for certain kinds of business activity. In Ivory Park, 32\% of all businesses' activities are situated on the high street; the corresponding figure for Tembisa is $34 \%$. This finding shows a higher percentage of business activity on the high street than the $23 \%$ recorded in the Western Cape sites (see Charman \& Petersen 2014). The kind of businesses situated on the high streets does vary, as shown in Figures 3 and 4 . Service-oriented businesses along with specialist services and micro-manufacturing tend to occupy high street locations. Although $20 \%-30 \%$ of grocery stores occupy high street positions, most are residentially situated, serving localised niche markets whose geographical scope typically falls within a radius of between $50 \mathrm{~m}$ and $100 \mathrm{~m}$. A similar spatial-economic logic accounts for the position of venues for liquor consumption and recreation with fewer than $15 \%$ of shebeens (unlicensed) situated on the high street.

Spatial logics not only determine where enterprises are situated but also influence the nature of the business infrastructure itself. On the high street, notably in places with high pedestrian density such as close to transport nodes, residential properties have been converted into business units that in turn sustain an infrastructure of signage, public entrances and veranda that encroach (and appropriate) public space. Permanent structures include containers, shacks, and kiosks, whilst semi-permanent stands include gazebos, tarpaulin and post, rudimentary trading

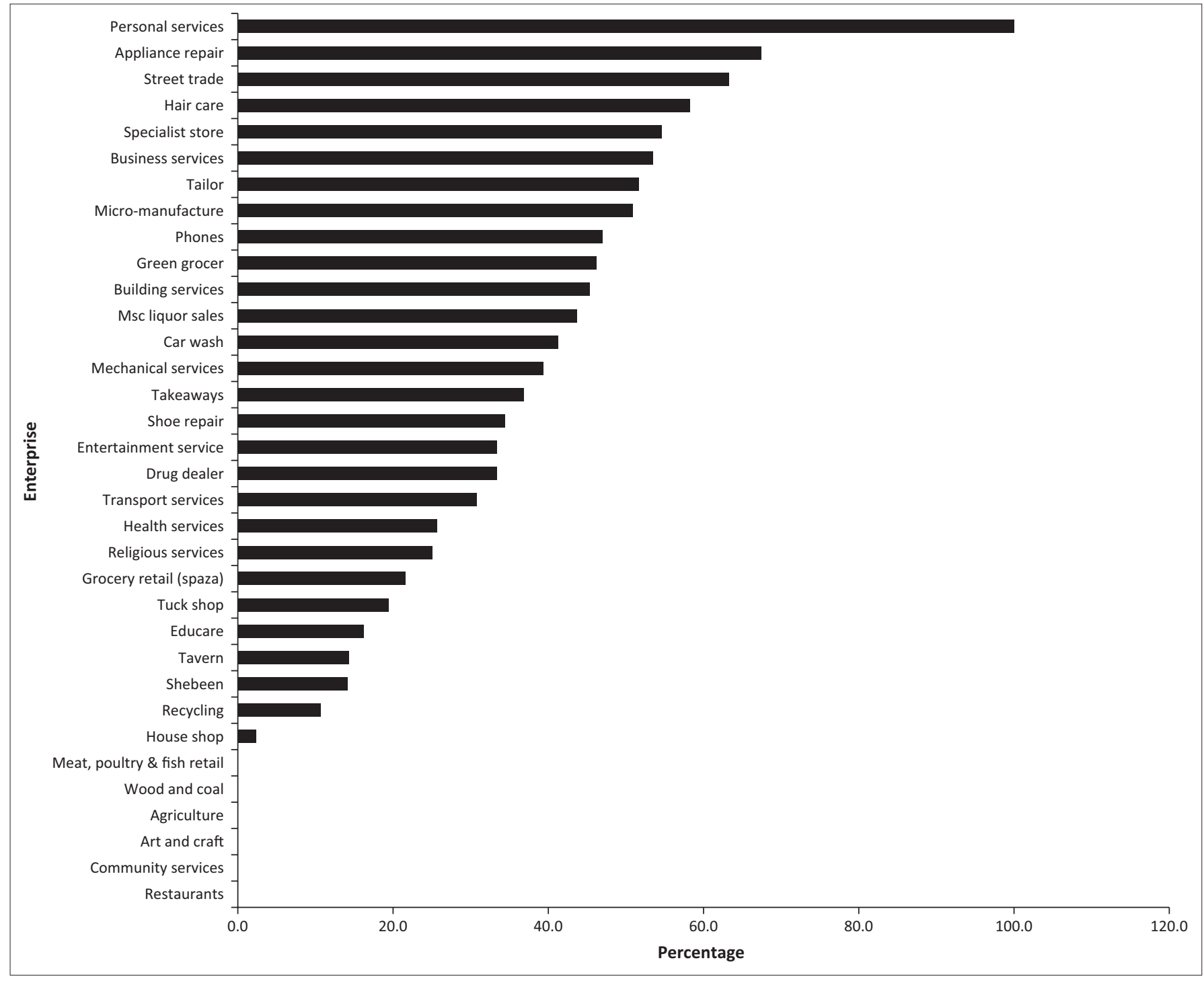

FIGURE 3: Ivory Park, percentage of enterprise category situated on the high street. 


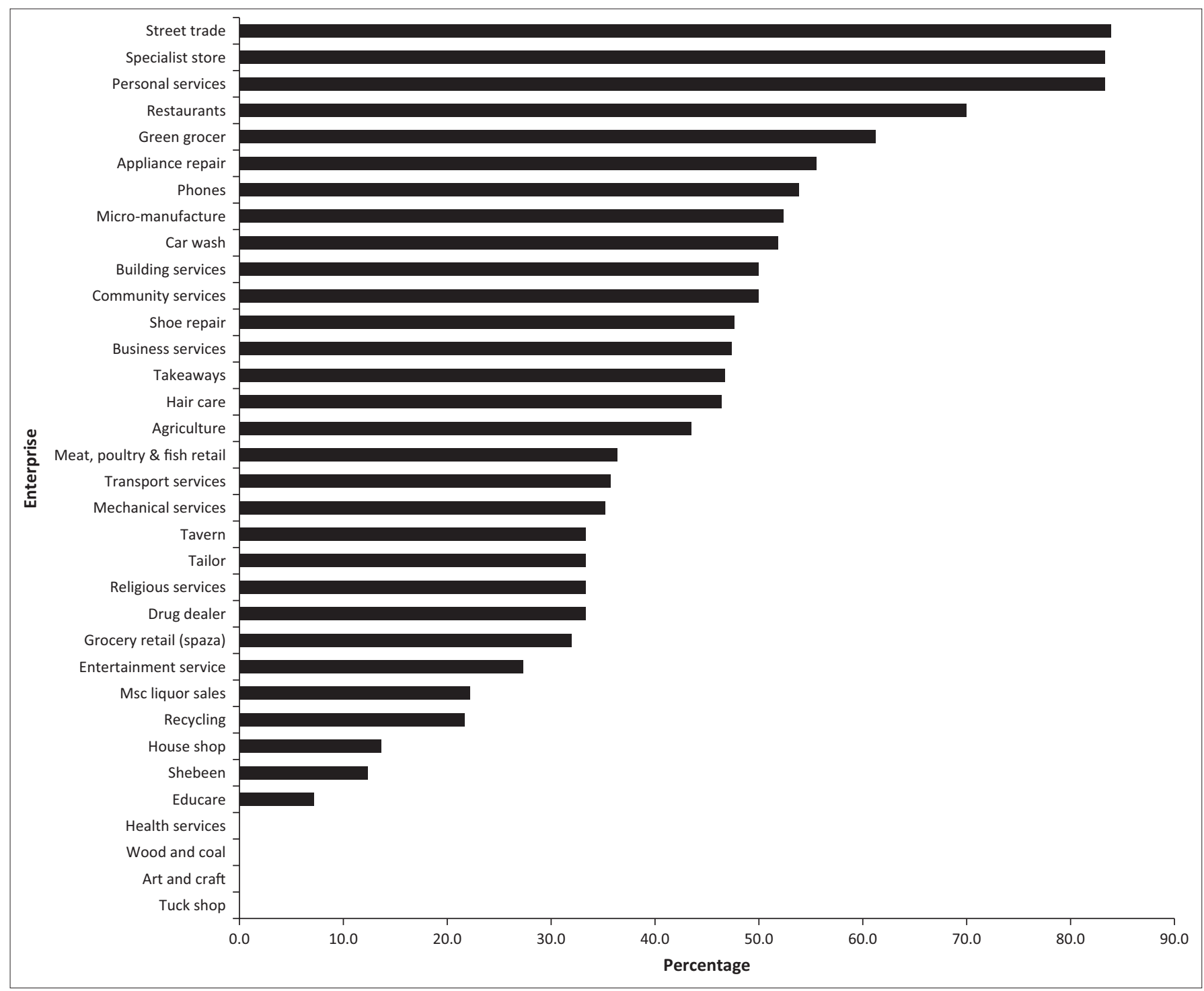

FIGURE 4: Tembisa, percentage of enterprise category situated on the high street.

counter and umbrella stands. Some traders use open land (for car repair and manufacturing activities) or display their goods on the ground. There are also a range of mobile businesses and entrepreneurs whose minimal space requirements enable them to position their trade in sites of high pedestrian density. In contrast, home-based businesses such as spaza shops tend to occupy a single room or outbuilding, such as a shack

\section{The entrepreneurs}

The characteristics of entrepreneurship vary from sector to sector. The data below (Tables 3, 4 and 5) refer to four sectors: grocery retail (spaza shops), taverns and shebeens, hair care and educare ${ }^{4}$ businesses. In comparing the results from the

4.Educares are home-based microenterprises that provide out-of-home care and educational services for children between the ages of 0 and 6 . Educares range in their size and business offering. Although some educares are formally recognised by local municipalities and departments of social welfare, others are largely informa. Those that are recognised are commonly eligible for subsidies per child. Although it is a requirement (at municipal and provincial levels of government) for these businesses to be registered with the municipality and/or Provincial Department fo Social Welfare and Development (DSWD), registration is seldom enforced.
TABLE 3: Business ownership and/or gender ( $\%$ of enterprise category).

\begin{tabular}{llllll}
\hline Site & Gender & Educare & Hair care & Tavern & Spaza \\
\hline Ivory Park & Male & 24.2 & 39.5 & 50.5 & 79.5 \\
& Female & 75.8 & 60.5 & 49.5 & 20.5 \\
Tembisa & Male & 7.1 & 55.6 & 50.9 & 81.5 \\
& Female & 92.9 & 44.4 & 49.1 & 18.5 \\
\hline
\end{tabular}

two sites, broad contours of entrepreneurship can be identified.

Spaza shops are predominately male-run businesses, a finding that might seem surprising given that spaza shops were historically thought of as business enterprises run equally by men and women (indeed, as family run entities). The result reflects the fact that nowadays merely 33\% of shops in Ivory Park and 37\% of shops in Tembisa are run by South Africans. Roughly $70 \%$ of all spaza shops are operated from rented premises with the landlords earning R1200 per month (median value). This suggests that the monthly return on labour did not justify the efforts of former shopkeepers in an environment which has become highly price competitive 
TABLE 4: Business ownership and/or county of nationality (\% of enterprise category).

\begin{tabular}{|c|c|c|c|c|c|c|c|c|c|c|c|}
\hline Site & Bangladesh & Ethiopia & Ghana & Lesotho & Malawi & Mozambique & Nigeria & Pakistan & South Africa & Somalia & Zimbabwe \\
\hline Ivory Park & - & - & - & - & - & - & - & - & - & - & - \\
\hline Educare & - & - & - & - & - & 4.3 & - & - & 95.7 & - & - \\
\hline Spaza & 10.1 & 24.9 & - & 0.5 & - & 19.4 & - & 0.5 & 33.2 & 4.6 & 6.9 \\
\hline Hair care & - & - & 1.1 & - & - & 14.1 & 1.1 & - & 31.5 & - & 52.2 \\
\hline Tembisa & - & - & - & - & - & - & - & - & - & - & - \\
\hline Tavern & - & - & - & - & - & - & - & - & 100 & - & - \\
\hline Spaza & 12.3 & 37.7 & - & 0.8 & - & 1.5 & - & - & 37.7 & 2.3 & 7.7 \\
\hline Hair care & - & - & 5.7 & - & - & 34.0 & - & - & 32.1 & - & 28.3 \\
\hline
\end{tabular}

TABLE 5: Business ownership and/or age (\% of enterprise category).

\begin{tabular}{|c|c|c|c|c|c|c|c|}
\hline Site & Sector & $0-19$ & $20-29$ & $30-39$ & $40-49$ & 50-59 & Over 60 \\
\hline \multirow[t]{3}{*}{ Ivory Park } & Tavern & 3 & 26 & 28 & 23 & 13 & 7 \\
\hline & Spaza & 5 & 41 & 28 & 15 & 8 & 2 \\
\hline & Hair care & 6 & 48 & 38 & 7 & 1 & 0 \\
\hline \multirow[t]{3}{*}{ Tembisa } & Tavern & 1 & 25 & 19 & 20 & 20 & 15 \\
\hline & Spaza & 2 & 41 & 32 & 14 & 7 & 4 \\
\hline & Hair care & 2 & 54 & 40 & 4 & 0 & 0 \\
\hline
\end{tabular}

Note: Age data on educares are not available.

(Piper \& Yu 2016). Overall, the majority of shops are run by (male) immigrant entrepreneurs and their workers, with Bangladeshis and Mozambicans in Ivory Park and Ethiopians and Bangladeshis in Tembisa having a strong presence in the sector. Taverns (inclusive of shebeens) and hair care businesses are equally run by men and women (liquor retail sees a particularly even gender-split), though the entrepreneurs derive from very different age segments. Hair entrepreneurs are generally persons of younger age; roughly half of all business owners are under 30 years of age. In contrast, fewer young people operate taverns, with $71 \%$ of tavern owners in Ivory Park and 75\% in Tembisa older than 30 years. Most liquor retailers are survivalist businesses, run merely to supplement household income. In terms of the volume of beer sold, $44 \%$ in Ivory Park and $49 \%$ of liquor sellers in Tembisa reported selling five or fewer crates $(12 \mathrm{~mL} \times 750 \mathrm{~mL})$ of beer per week, thus earning potentially less than R100 in profit. Yet these individuals are willing to run the risk of police raids, arrest and prosecution such is their desperate need to supplement income.

The data on the educational background of the business owners are patchy, apart from the hair care sector where this information is most reliable. The data set comprises 133 responses. Only one individual had obtained a post-tertiary qualification. At the other end of the spectrum, a handful of individuals have no schooling. Most of the salon owners have either obtained matric ( $24 \%$ in Ivory Park; $27 \%$ in Tembisa) or completed some level of high school education. As a sector characterised by young entrepreneurs, it appears that many of the persons owning and working in salons have dropped out of school. It is possible that salon work has acquired a reputation as 'work for drop-outs', therefore lessening the attractiveness of the sector for persons interested in pursuing post-school training in the field of hair care. As in the spaza sector, South African hair salon entrepreneurs are a minority, comprising $32 \%$ of businesses in both Ivory Park and Tembisa. In contrast, over $60 \%$ of the salons in both sites are operated by nationals from Mozambique and Zimbabwe. The renowned Franco and West African barber shops, ubiquitous in some townships and settlements (Weller 2011), are largely absent apart from four Ghanaian barbers.

Most hair salons are run by the owners (73\% in Ivory Park and $88 \%$ in Tembisa). Spaza shops and tavern and/or shebeens are categories in which employment is frequently observed, see Table 6. The data on spaza shops show that around one-third of shops (36\% in Ivory Park and $26 \%$ in Tembisa) are owneroperated. Approximately half of all shops employ one person (in addition to the owner) (48\% in Ivory Park and 53\% in Tembisa) and $19 \%$ of shops in Tembisa employ two persons (the comparative figure for Ivory Park is $12 \%$ ). Most of the South African-run spaza shops are single-worker enterprises. Taverns have a potentially high demand for labour, though much work is performed by part-time workers and family members. This is a sector that is largely dominated by South African entrepreneurs, self-employed men and women, apart from a minority of Mozambican and Zimbabweans businesses (28 in total; $8 \%$ of category) in Ivory Park. There were 62 licensed liquor outlets in Tembisa (37\% of category) and 39 (11\% of category) in Ivory Park. The capacity of unlicensed shebeen owners (the majority of outlets) to operate on-consumption venues is influenced by the generalised state of informality (e.g. there are more shebeens in informal settlements) and localised risk factors relating to police action from raids and tribute extraction. For this reason, merely $40 \%$ of liquor traders in Tembisa have on-consumption venues and only 30\% in Ivory Park; in both sites most liquor retailers sell for off-consumption. Off-consumption venues have a lower labour requirement. Only $13 \%$ of taverns and/or shebeens in Tembisa provide employment for one additional person; this finding indicates that obtaining a liquor licence does not, in itself, foster employment growth. The corresponding figure in Ivory Park is 35\%. In the 2 sites, the research identified 
TABLE 6: Employment (\% within enterprise category).

\begin{tabular}{|c|c|c|c|c|c|c|c|c|c|c|}
\hline \multirow[t]{2}{*}{ Site } & \multirow[t]{2}{*}{ Category } & \multicolumn{9}{|c|}{ Employees (including owner) } \\
\hline & & 1 & 2 & 3 & 4 & 5 & 6 & 8 & 9 & $>10$ \\
\hline \multirow[t]{2}{*}{ Ivory Park } & Tavern & 52 & 35 & 6 & 3 & 3 & 1 & 0 & 0 & 1 \\
\hline & Spaza & 36 & 48 & 12 & 1 & 1 & 0 & 0 & 0 & 0 \\
\hline \multirow[t]{2}{*}{ Tembisa } & Tavern & 74 & 13 & 7 & 1 & 1 & 2 & 1 & 1 & 1 \\
\hline & Spaza & 26 & 53 & 19 & 2 & 0 & 0 & 0 & 0 & 0 \\
\hline
\end{tabular}

17 venues in Ivory Park (13\% of category) that provided employment to 2 or more persons and 19 such venues $(12 \%$ of category) in Tembisa. The results on employment in the liquor retail sector should be interpreted with caution because informants might under-report the role of family labour as well as casual services. The researcher encountered numerous young men working as freight handlers, transporting liquor using trollies, wheelbarrows and wheelie bins to move stock between supplier and retailer.

The educare sector is an outlier in the provision of employment. All bar one of the businesses we surveyed were run by South Africans, who as mentioned above are mostly women, whilst $88 \%$ of educares are owner-operated. Most educares had been running for several years ( 9 years median in Ivory Park; 4 year median in Tembisa), and it seems that rarely does business ownership transfer from one entrepreneur to another (partly because of the infrastructure requirement). As can be expected, educares have a relatively high labour requirement. Less than $12 \%$ of the educares in Ivory Park and $17 \%$ in Tembisa are singleperson operations. The employment profile differs between the sites with about $48 \%$ of educares in Tembisa employing three or more persons, though in Ivory Park over $80 \%$ of educares employ three or more persons. The registration of educares with the Department of Social Welfare and Development impacts the characteristics of the enterprise. Sector registration enables the enterprise to gain access to pupil subsidies, and the regulatory criteria compel the businesses to invest in facilities and adopt minimum standards. The registered businesses employ more workers. Yet only half the educares in the survey were registered. Informants report that the obstacles to registration include landuse zoning, the lack of space within homes and insufficient resources to meet all the compliance criteria.

\section{Pathways into business}

The interviews with the owners indicate that there are four main pathways by which people establish businesses. The first relates to what is referred to as 'make work jobs': these usually start out as livelihood strategies through which persons that are unemployed seek to make 'ends meet' utilising whatever assets and resources are accessible and affordable. The business then unfolds, developing a scale that was unimaginable at the outset, confirming that survivalist businesses can grow beyond initial projections. Steve (Informant 1698), to provide one example, runs a spaza shop in Ivory Park. He started the shop 13 years ago with R700 after he lost his job. He set up the business in a portion of his mother's house and after a while the business did sufficiently well to enable him to buy out his mother's house.
The second pathway is based on the acquisition of skills, onthe-job experience and access to the market or customers through working. Young entrepreneurs in the entertainment sector, such as disk jockeys, acquire their skills through their hobby of making and/or playing music which, in turn, can process into a business as their craft gains reputation. On-thejob skills acquisition is an important pathway for employees to acquire entrepreneurial skills. This route to entrepreneurship in the hair care sector is common, as in the case of Monica's (2594) business. A Mozambican national, she started plaiting hair in a salon where she acquired her skills and then when she had accumulated enough money she set up in business on her own, taking some of the customers with her. She has one employee and makes about R2500 per month.

The third pathway is through a strategic investment to establish the business. In many cases the investor is not involved in the running of the business; either they have a job which provides the source of investment capital or they own other businesses. Many of the immigrant run spaza shops have been established by investors, either through setting up new shops or buying out struggling businesses. Spaza shops are now often bought and sold. In response to a question about whether the business could be purchased and the possible sales price, the research learnt that well-stocked spaza shops in Ivory Park and Tembisa sell for between R60 000 and R85 000 on average. But the spaza scenario in which entrepreneurs purchase established businesses with the objective of selling them at a profit is not evident in other sectors. Usually, the investment sums are smaller and the business is started from scratch. Martin (2697), for example, purchased his salon (excluding building) from an individual for R2000 after seeing an advertisement posted in the street. Upon acquiring the business, he maintained the lease agreement with the property owner, paying R200 per month for rent, water and electricity.

Successful township entrepreneurs often diversify their investments in a range of sectors or acquire multiple outlets. Shifting investment away from the core business is done to minimise risks (theft, state regulation and jealously, to mention some of the explanations provided). It is not uncommon for successful entrepreneurs to own minibus taxis, provide school transport services and operate a tavern, spaza shop or butchery. In the survey of tavern owners, for example, 9\% had other business interests, most commonly a spaza shop, then meat and food scales (take away), recycling and rental income.

A fourth pathway is where the businesses are passed on within the extended family, such as from parents to children. 
TABLE 7: Perceived obstacles to enterprise growth (\% responses and/or categories).

\begin{tabular}{|c|c|c|c|c|c|c|c|c|c|c|c|c|}
\hline Site & Sector & Laws & Licensing & $\begin{array}{l}\text { Police } \\
\text { harassment }\end{array}$ & Finance & Non-payment & Unemployment & Competition & Crime & $\begin{array}{l}\text { Location and } \\
\text { infrastructure }\end{array}$ & Facilities & Other \\
\hline Ivory Park & Educare & 37 & - & - & 40 & 17 & - & - & - & 37 & 31 & - \\
\hline Tembisa & Educare & 9 & - & - & 56 & 13 & - & - & - & 13 & 19 & - \\
\hline Ivory Park & Tavern & - & 17 & 33 & 11 & - & 8 & - & 23 & 13 & - & 34 \\
\hline Tembisa & Tavern & - & 7 & 12 & 10 & - & 2 & - & 28 & 5 & - & 21 \\
\hline Ivory Park & Spaza & 3 & 7 & 7 & 27 & - & - & 12 & 10 & 12 & - & 15 \\
\hline Tembisa & Spaza & 5 & - & 4 & 23 & - & - & 24 & 33 & 7 & - & 5 \\
\hline Ivory Park & Hair care & 1 & - & - & 27 & - & - & 14 & 3 & 20 & 11 & 29 \\
\hline Tembisa & Hair care & - & - & - & 36 & - & 2 & 15 & 5 & 15 & 2 & 27 \\
\hline
\end{tabular}

There are fewer cases of this pathway within the data set. Where a business requires a licence or operates from a permanent structure or has accumulated business assets, there is a greater rationale for maintaining the business within the family as an ongoing concern.

\section{Obstacles}

What do the entrepreneurs regard as their main obstacles in growing their enterprise and what are their strategies to overcome these challenges? Firstly, it should be recognised that some owners passively accede to the lowly state of their business and have no intention to pursue growth. This is not uncommon in the informal economy where markets are established on a confluence of commercial and social rationales (see Neves \& Du Toit 2012). Jane (2399 has run an educare for 4 years and has grown the business from looking after 5 children to 32 children, enabling her to make a profit of R4000 per month. She has no intention of further expansion. Like Joyce, several of the educare owners saw their business in an altruistic light, offering a service to the community 'so parents could go job hunting' (2400). The great majority of the business endeavours in the food-drink range constitute livelihood strategies and to speak of a micro-enterprise misrepresents the state of these activities. These are survivalist businesses: individuals trade so long as they make some income (however small), though would abandon the business to pursue better opportunities (such as employment) when and where the opportunity arises. A few will see their business grow. But is there a ceiling to this growth? The answer to this question is probably 'yes', though of course outliers can transcend the obstacles. There are many examples where a survivalist entrepreneur grows the business from point zero to the point of deriving a stable income. But it would seem that rarely can these entrepreneurs take the business to the next level, acquiring property, fixed assets, employing permanent staff and formalising their business.

The research invested perceived obstacles to enterprise growth; see Table 7. The researcher employed a mixed method approach, recording qualitative responses (open ended) and enumerating barriers where specifically named. The data were subsequently recoded under the heading listed in the table; the data indicate the percentage of responses by category and site. Across the four categories, shortage of finance is the most common listed. This obstacle refers to both investment capital and working capital. In the educare sector, the result potentially relates to the aim of entrepreneurs to access state subsidies. It should be noted that the provision of credit is central to the working of the township economy. Businesses have poor access to finance, but trade in a market with high credit demand. The research encountered credit provided at spaza shops, taverns and/or shebeen, by street traders (including hawkers, though excluding food service businesses) and clothing shops. All payments are settled in cash. Across both sites, the researcher found no business with electronic payment services. Access to finance in the hair care sector impacts the capacity of the entrepreneur to invest in products, equipment and facilities, and (importantly) change the location from which the business operates.

Regulatory barriers affect educares, tavern and/or shebeens and spaza shops, especially those that trade (illicitly) in liquor. In the case of liquor traders, more informants identified police harassment as a barrier than licensing or other laws. The twin obstacles of licensing and police harassment were more commonly cited by liquor traders in Ivory Park, where (as previously noted) merely $11 \%$ of microenterprises have liquor licences. Small survivalist liquorselling businesses were less affected by crime, though larger businesses had to deal with armed robbery (28 businesses) and other kinds of theft. A particular challenge for unlicensed shebeen operators is posed by conmen who offer to assist the business owners acquire liquor licences. Crime impacts heavily spaza shops, with Tembisa spaza traders more commonly affected by crime than their counterparts in Ivory Park (33\% of responses vs. 10\%). In the spaza sector, with respect to a separate question, 82 shopkeepers (23\% of the category) recalled incidents of robbery and/or theft over the past 5 years, with incidents of crime affecting all nationalities equally on both sites. Other reports of crime (across all sectors) included the use of counterfeit notes, non-payment of debts, social and political harassment and extortion from petty thugs (for cigarettes from spaza shops). Complaints about police raids, fines and stock confiscation are surprisingly common in the spaza sector, especially amongst those businesses selling beer. Yet immigrant shopkeepers (who do not sell beer) also complained about police raids which are undertaken in the name of searching for illegal (grey market) cigarettes (sold widely in most shops). 
An obstacle listed across all four sectors are the challenges presented by the business location (disadvantages of the place at which the enterprise operates) and / or the inadequacy of the infrastructure out of which the business trades. The comparatively greater number of responses to this variable amongst Ivory Park entrepreneurs (37\% vs 13\% in educare; $20 \%$ vs. $15 \%$ in hair care) is due, in part, to the insecurity of business tenure as a result of the informality in land-use and ownership. Many hair care businesses operate on the street verge. In hair care and educare sectors, lack of physical space to extend the business infrastructure was commonly identified as an obstacle to growth. These entrepreneurs would want to expand their premise but cannot access land. Another challenge is that high street salons are not connected to the municipal water and sewerage lines; most of them use buckets to access water. Several of the educare owners spoke of the absence of space for children to play, inadequacy of the toilets and crammed conditions in classrooms. Space constraints sorely affect the possibilities of taverns to provide adequate seating, recreational facilities and storage. Liquor products are thus stored in the house, and thresholds between public and private space overlap and compete for space. In the spaza sector, it is not uncommon for the shopkeeper(s) (especially immigrants who rent the shop building) to sleep within the store.

The challenge of business competition was persistently reported by South African spaza shop keepers (12\% in Ivory Park; $24 \%$ in Tembisa) as well as entrepreneurs running educares (data omitted in quantitative survey) and hair salons (14\% Ivory Park; 15\% Tembisa). At the time this research was undertaken, a number of South Africans spaza shops had closed because of competition. For those continuing in business, such as Zandile (Informant 1877), she responded to increasing competition through lowering her prices, providing credit and selling alcohol. An often cited strategy for addressing competition is to shift to a new locality. It is noteworthy that many respondents gave enterprise specific responses to the question of growth obstacles. These are recorded under 'other'. The factors mentioned ranged from issues of a socioculturalpsychological dimension (such as jealously, witchcraft and bad luck), to external shocks on the household (resulting from death and disability), to relationships problems issues within the family. Other issues were high transport costs, tenancy disputes and electricity supply issues. Immigrants specifically complained of their inability to acquire bank accounts. There is minimal evidence that people work cooperatively, for example, to enhance purchasing power. This was cited as a cause of poor competitiveness amongst some South African informants. Eddie (Informant 1531), for example, once ran a spaza, which he now rents out to Ethiopian shopkeepers. He endeavoured to create a 'collective association' to enable bulk purchasing. But no one was willing to join him. He explained 'people refused because of a lack of trust, a lack of education, they did not understand how much more profitable the business of spaza shops could be'. In contrast, the research came across several cases of stokvel groups working effectively to mobilise finance and enhance business opportunities. These self-selecting groups are highly effective in enforcing compliance with the stokvel rules.

\section{Conclusion: Potential for growth?}

The paper has sought to outline the state of the township economy in two different localities. The overall situation is cause for concern, even though there is considerable evidence of livelihood resilience and entrepreneurship. Although we cannot extrapolate our results across other township settlements, the data on the two case sites are rigorous (based on a census approach), insightful in qualitative terms and provide a compelling perspective on what business activities occur, where people conduct business, how they get into business, what constraints the entrepreneurs have to confront and, finally, reflect on the common business strategies that have been pursued to achieve growth. The research found a surprising consistency between Ivory Park and Tembisa in the scale, scope and spatial distribution of micro-enterprises, despite their socio-demographic, spatial and historical differences. The results are also not dissimilar to the state of entrepreneurship in five townships in the Western Cape that were studied using the same methodological approach (Charman \& Petersen 2014) or indeed the findings from Diepsloot (Mahajan 2014; Mengistae 2014).

Based on this insight into township micro-entrepreneurship, we return to the question posed at the outset, namely what should government do to stimulate the township economy? A simple answer is to keep strategies low-geared, focusing on achievable results. Ambitious plans to change the structure of the economy towards manufacturing and non-food and/or drink retail are likely to disappoint and will not benefit the majority of existing businesses. Throughout the paper the issue of space is mentioned. There is a need to make land available for business expansion. People need title deeds to formalise market transitions and invest in property assets. The current land-use zoning approach is illogical. Townships are mixed business area and should be recognised as such. The street environment is central to businesses, and trading in particular should be legitimised and respected, whilst municipal authorities should seek to maximise the use of the street including verges and unutilised land for business activities without overly prescribing the manner in which the space is utilised. Mobility is crucial to most businesses. Municipal authorities should be accommodating towards diverse forms of transport including trollies, push-carts and the like. Street lighting can lengthen the business day, allowing traders to target markets at times when they are busiest: early in the morning and evening. Infrastructure for business would also help, especially in places of dense trading, but as infrastructure needs to be inclusive of a range of spatial requirements it should not comprise homogenous units, laid in geometric order. Instead, infrastructure should permit the flexible and fluid use of facilities, reflecting business needs and spatial requirements, organised and managed through participatory processes. 
In sectors where regulation is deemed necessary, the requirements should be positioned at the capacity of the micro-enterprise and the capability of the entrepreneurs, recognising that township entrepreneurs are disadvantaged vis-à-vis formal businesses. A process of 'facilitating formalisation' (Williams \& Nadin 2012, 2014) must have a developmental approach. Compliance processes need to be simple with benchmarks set out to enable the business to achieve full regulatory compliance through a growthoriented process. This will give the enterprise time to grow, reinvest resources in the businesses and, most importantly, to respond to failure. Adherence to regulation needs to be monitored, but not by authorities who have the power to extract tribute but rather it should be undertaken by technical specialists who can simultaneously advise on corrective action. The police should not be afforded a front-line role in managing the 'where', 'when' and 'how' business is conducted but mobilised only when non-compliance is persistent or public safety materially threatened. Training, whether in business or technical skills, is not a panacea. None of the study informants bemoaned 'skills shortage'. Government resources would be better spent funding young people who desire to attend college to acquire skill; they may one day return to open up a business in the township. Micro-credit is obviously needed, though credit is notoriously difficult to target the right people who will use the money in the manner intended. Those organisations that work closest to the micro-entrepreneurs are probably best placed to deliver a service that meaningfully benefits the business though such a developmental service comes with high overhead costs. A different approach may be to channel lending through established stokvels, enabling the group to lend resources to its members on terms that the group can contractually uphold. Previous approaches in this respect have had promising results (Sebstad 1992). The role of immigrant entrepreneurs needs to be accepted and where justifiable (in the case of larger businesses) compelled to formalise. A simple first step would be enabling immigrant entrepreneurs to establish bank accounts.

National government has the core responsibility to tackle crime. Yet the role of the police needs to be carefully strategised, especially in enforcement of regulatory compliance where opportunities for bribery and the abuse of power are difficult to prevent. Finally, government should be encouraged to refocus its attention on markets that have greater potential for productivity enhancement of township residents. This requires rethinking the spatial implications of township revitalisation. Township entrepreneurs may achieve greater success selling goods and services outside the geographical confines of the township, in inner-city or suburban neighbourhoods. These markets are more lucrative and sustain demand for a greater diversity of goods and services. Yet municipal policies have a determining impact on where, when and how micro-enterprises may operate, usually with the intention to either control or exclude. The institutional incongruence between national, provincial and municipal objectives should be redressed. Thinking differently entails not only liberating new market places and spaces outside the township but also ensuring that the township poor have the priority to operate businesses in these contexts.

\section{Acknowledgements}

The research was commissioned by the Sustainable Livelihoods Foundation. The author thus acknowledges them for making available the data on which this article is based. The research findings and conclusions are those of the author alone and the Foundation had no influence on either the interpretation of the data or on the author's decision to publish the findings. The author acknowledges the Rockefeller Foundation's Bellagio residency programme during which time the article was written. The author acknowledges the research support of colleagues Leif Petersen, Rory Liedeman and Caitlin Tonkin. The author benefited from the comments of the South African Journal of Economic and Management Sciences editors and two anonymous reviewers.

\section{Competing interests}

The author declares that he has no financial or personal relationships that may have inappropriately influenced him in writing this article.

\section{References}

Bayat, A., 1997, 'Un-civil society: The politics of the "informal people"', Third World Quarterly 18(1), 53-72. https://doi.org/10.1080/01436599715055

Benit-Gbaffou, C., 2015, In quest for sustainable models of street trading management CUBES, University of Witwatersrand, Johannesburg.

Charman, A., Herrick, C. \& Petersen, L, 2014, 'Formalising urban informality: Microenterprise and the regulation of liquor in Cape Town', The Journal of Moder African Studies 52(4), 623-646. https://doi.org/10.1017/S0022278X14000615

Charman, A. \& Petersen, L., 2014, Informal micro-enterprises in a township context. A spatial analysis of business dynamics in five Cape Town localities, REDI3×3 Working Paper 5, Research Project on Employment, Income Distribution and Inclusive Growth, SALDRU, University of Cape Town, Cape Town.

Charman, A., Petersen, L. \& Piper, L., 2012, 'From local survivalism to foreign entrepreneurship: The transformation of the spaza sector in Delft, Cape Town' Transformation: Critical Perspectives on Southern Africa 78(1), 47-73. https://doi. org/10.1353/trn.2012.0035

Charman, A. \& Piper, L., 2013, 'Xenophobia, criminality and violent entrepreneurship: Violence against Somali shopkeepers in Delft South, Cape Town, South Africa', South African Review of Sociology 43, 81-105. https://doi.org/10.1080/21528586 2012.727550

Charman, A.J.E., Petersen, L.M., Piper, L.E., Liedeman, R. \& Legg, T., 2015, 'Small area census approach to measure the township informal economy in South
Africa', Journal of Mixed Methods Research 11(1), 1-23. https://doi.org/10.1177/ Africa', Journal of Mixed
1558689815572024

Cichello, P., Almeleh, C., Mncube, L. \& Oosthuizen, M., 2011, Perceived barriers to entry into self-employment in Khayelitsha, South Africa: Crime, risk and start-up capital dominate profit concerns, Working Paper 300, Centre for Social Science capital dominate profit concerns, Working Paper 300, Centre for Social Science
Research, Aids and Society Research Unit, University of Cape Town, Cape Town.

Creswell, J.W., 2014, Research design, 4th edn., Sage, London.

FinScope, 2010, Finscope, South Africa: Small business survey, Finmark Trust, Johannesburg.

Fourie, F., 2015, The NDP on unemployment: On consistency, coherence and comprehensiveness, REDI3×3 Working Paper 7, Research Project on Employment, Income Distribution and Inclusive Growth, SALDRU, University of Cape Town, Cape Town.

Fox, L. \& Sohnesen, T.S., 2012, Household enterprises in Sub-Saharan Africa. Why they matter for growth, jobs, and livelihoods, Policy Research Working Paper 6184, The World Bank, Washington, DC.

Gauteng Province. Gauteng Department of Economic Development, 2015, Revitalisation of the township economy, strategy (draft), Gauteng Province, Johannesburg.

Gulyani, S. \& Talukdar, D., 2010, 'Inside informality: The links between poverty, microenterprises and living conditions in Nairobi's slums', World Development 38(12), 1710-1726. https://doi.org/10.1016/j.worlddev.2010.06.013

Liedeman, R., 2012, 'Understanding the internal dynamics and organisation of spaza shop operators: A case study of how social networks enable entrepreneurialism amongst Somali but not South African traders in Delft South, Cape Town', MA thesis, University of Western Cape. 
Ligthelm, A., 2005, 'Informal retailing through home-based micro-enterprises: The role of spaza shops', Development Southern Africa 22(2), 199-214. https://doi. role of spaza shops', Development
org/10.1080/03768350500163030

Ligthelm, A., 2006, 'Size estimate of the informal sector in South Africa', Southern African Business Review 10(2), 32-52.

Ligthelm, A., 2008, 'The impact of shopping mall development on small township retailers', South African Journal of Economic and Management Sciences 11(1), 37-53.

Mahajan, S. (ed.), 2014, Economics of South African Townships. Special focus on Diepsloot, The World Bank, Washington, DC.

Mahon, T., 2010, 'Digi-Mart. An interactive "SUPER" market that enhances the social and technological conditions in Ivory Park', MA thesis, University of Witwatersrand.

McPherson, M.A., 1996, 'Growth of micro and small enterprises in southern Africa', Journal of Development Economics 48, 253-277. https://doi.org/10.1016/0304 3878(95)00027-5

Mead, D.C. \& Liedholm, C., 1988, 'The dynamics of micro and small enterprises in developing countries', World Development 26(1), 61-74. https://doi.org/10.1016/ S0305-750X(97)10010-9

Mengistae, T., 2014, 'Diepsloot's investment climate', in S. Mahajan (ed.), Economics of South African Townships. Special focus on Diepsloot, pp. 179-218, The World Bank, Washington, DC.

Mukhopadhyay, P., 2011, Formality and functionality in Indian cities, Seminar, New Delhi, p. 617.

Nemasetoni, I. \& Rogerson, C.M., 2005, 'Developing small firms in township tourism: Emerging tour operations in Gauteng, South Africa', Urban Forum 16(2-3), 196213. https://doi.org/10.1007/s12132-005-1005-9

Neves, D. \& du Toit, A., 2012, 'Money and sociality in South African informal economy', Africa 82(1), 131-149. https://doi.org/10.1017/S0001972011000763

Petersen, L.M., Charman, A.J.E., Moll, E.J., Collins, R.J. \& Hockings, M.T., 2014, “"Bush doctors and wild medicine": The scale of trade in Cape Town's informal economy of wild-harvested medicine and traditional healing', Society \& Natural Resources 27(3), 1-22. https://doi.org/10.1080/08941920.2013.861558

Piper, L. \& Yu, D., 2016, 'Deconstructing "the Foreign": The limits of citizenship for explaining price competition in South African Spazas', Development Southern Africa 33(5), 658-676. https://doi.org/10.1080/0376835X.2016.1203758
Rogerson, C.M. \& Beavon, K.S.O., 1982, "Getting by in the "informal Sector" of Soweto', Tijdschrift Voor Economische En Sociale Geografie 73(4), 250-265. https://doi.org/10.1111/j.1467-9663.1982.tb00962.x

Rolfe, R., Woodward, D., Ligthelm, A. \& Guimarães, P., 2010, 'The viability of informal micro-enterprise in South Africa', presented at the Conference Entrepreneurship in Africa, Whitman School of Management, Syracuse University, Syracuse, New York, 1-3 April.

Sebstad, J., 1992, Get ahead foundation credit programs in South Africa: The effects of loans on client enterprises, Gemini Technical Report No. 44, Gemini, Maryland, United States.

Scott, L. \& Barr, G., 2013, 'Unregulated gambling in South African townships: A policy conundrum?', Journal of Gambling Studies 29(4), 719-732. https://doi. org/10.1007/s10899-012-9330-0

Skinner, C., 2008, Street trade in Africa: A review, WIEGO Working Paper No. 5, WIEGO, Cambridge USA.

Statistics South Africa, Population census 2011, viewed n.d., from https://www. census2011.co.za

South African History Archive (SAHA), n.d. Entering Tembisa, viewed 24 February 2016, from http://www.saha.org.za/tembisa/establishment_of_tembisa.htm

Webb, J.W., Bruton, G.D., Tihanyi, L. \& Ireland, R.D., 2013, 'Research on entrepreneurship in the informal economy: Framing a research agenda', Journal of Business Venturing 28, 598-614. https://doi.org/10.1016/j.jbusvent.2012.05.003

Weller, S., 2011, South African township barbershops \& salons, Mark Batty Publisher New York.

Williams, C.C., \& Nadin, S.J., 2012, 'Tackling entrepreneurship in the informal economy: Evaluating the policy options', Journal of Entrepreneurship and Public Policy 1(2), 2045-2101. https://doi.org/10.1108/20452101211261408

Williams, C.C. \& Nadin, S.J., 2014, 'Facilitation of the formalisation of entrepreneurs in the informal economy. Towards a variegated policy approach', Journal of Entrepreneurship and Public Policy 3(1), 33-48. https://doi.org/10.1108/JEPP-052012-0027

Wills, G., 2009, 'South Africa's informal economy: A statistical profile', Urban Policies Research Report, No. 7, WIEGO, Cambridge, United States.

Yu, D., 2012, 'Defining and measuring informal employment in South Africa', Development Southern Africa 29(1), 157-175. https://doi.org/10.1080/037683 5X.2012.645649 